\title{
Retraction Note to: Light hydrocarbon geochemistry: insight into oils/condensates families and inferred source rocks of the Woodford-Mississippian tight oil play in North-Central Oklahoma, USA
}

\author{
Ting Wang ${ }^{1,2} \cdot$ Dong-Lin Zhang ${ }^{1} \cdot$ Xiao-Yong Yang ${ }^{1} \cdot{\text { Jing-Qian X } \mathrm{X}^{1} \cdot \text { Coffey Matthew }}^{3} \cdot$ You-Jun Tang ${ }^{1}$
}

Published online: 15 October 2020

(c) The Author(s) 2020

\section{Retraction Note to: \\ Petroleum Science (2020) 17:582-597 \\ https://doi.org/10.1007/s12182-020-00441-1}

The authors have retracted their article (Wang et al. 2020) because of significant textual overlap with previously published works (Atwah et al. 2019; Wang and Paul Philp 2019).

All authors agree with this retraction.

Open Access This article is licensed under a Creative Commons Attribution 4.0 International License, which permits use, sharing, adaptation, distribution and reproduction in any medium or format, as long as you give appropriate credit to the original author(s) and the source, provide a link to the Creative Commons licence, and indicate if changes were made. The images or other third party material in this article are included in the article's Creative Commons licence, unless indicated otherwise in a credit line to the material. If material is not included in the article's Creative Commons licence and your intended use is not permitted by statutory regulation or exceeds the permitted use, you will need to obtain permission directly from the copyright holder. To view a copy of this licence, visit http://creativecommons.org/licenses/by/4.0/.

\section{References}

Atwah I et al. Light hydrocarbon geochemistry: insight into Mississippian crude oil sources from the Anadarko Basin, Oklahoma, USA. Geofluids. 2019.

Wang T, Paul Philp R. Oil families and inferred source rocks of the Woodford-Mississippian tight oil play in northcentral Oklahoma. AAPG Bull. 2019;103(4):871-903.

Wang T, Zhang D, Yang X, et al. Light hydrocarbon geochemistry: insight into oils/condensates families and inferred source rocks of the Woodford-Mississippian tight oil play in North-Central Oklahoma, USA. Pet Sci. 2020;17:582-97.

The original article can be found online at https://doi.org/10.1007/ s12182-020-00441-1.

You-Jun Tang

tyj@yangtzeu.edu.cn

1 Key Laboratory of Exploration Technologies for Oil and Gas Resources (Yangtze University), Ministry of Education, Wuhan 430100, Hubei, China

2 School of Geology and Geophysics, University of Oklahoma, Norman, OK 73019, USA

3 Devon Energy Corporation, Oklahoma City, OK 73102, USA 